\title{
Symbols, sagas, rites, and rituals An overview of organizational culture in libraries
}

\section{$\mathbf{W}$} hether as a fresh graduate of library school or a seasoned librarian, starting a job at a new library can be a daunting challenge. Besides having to learn the basics of a new job, the new librarian must learn the ins and outs of the organization. While the profession of librarianship shares many values and modes of behavior, individual libraries, whether academic, public, or special, can vary greatly in how they expect those within the organization to relate to one another. This can be most blatantly seen when, after a particularly egregious faux pas, a new librarian is pulled aside and told, "We do not do that in this library." The force which guides this behavior is organizational culture. Those within a library may have a difficult, if not impossible, time trying to explain the library's culture. Culture has to be experienced to be truly understood, but for library staff, librarians, and administrators, new or old, understanding the library's organizational culture is crucial in today's ever-changing world.

Organizational culture evolves over time and derives from the shared beliefs, values, and norms of the organization. It creates an identity, sense of purpose and meaning, and makes its members part of a larger whole. Organizational culture facilitates integration of new members, and fosters commitment to the organization from all of its members. Culture gives meaning to the work and mission of the organization, and acts as an overall guiding force for all those working within the organization. Just like the culture of a society, organizational culture influences and controls the behavior of its subjects and colors how they view the world and construct reality.
Organizational culture can both illuminate the reason for a particular action and dictate the action take place. It explains all of the tacit complexities of organizational life, and is expressed in a variety of ways, including symbols, ceremonies, and stories. It is most easily defined as, "That's how we do things around here."

Culture is taught to a library's new members both formally through the orientation process and the rites and rituals of the library and informally through one-on-one interaction among librarians and library staff. How the culture is imparted to newcomers is critical in determining the strength and effectiveness of a culture. If those who are new to an organization learn the culture fully and well, then the culture will become stronger. But if newcomers do not learn the culture at the beginning of their tenure, or they learn incompletely, then the culture, over time, will become weak. A strong culture can help an organization like a library endure rough times, especially during a financial crisis.

Organizational culture consists of sociability and solidarity; the relative strength or weakness of these two components determines the type of culture present. No one right culture exists; the culture of an organization must match its mission and environment. In fact, rarely does an organization have just one culture. Organizations are generally comprised of one dominant culture and several smaller subcultures. In order to study and

Jason Martin is associate librarian at University of Central Florida Libraries, e-mail: jason.martin@ucf.edu

(C) 2012 Jason Martin 
understand organizational culture, a typology can be used (i.e., clan culture, corporate culture, mercenary culture) or a more in-depth framework like Edgar Schein's five levels of cultural assumptions may be employed.

A study of culture may be undertaken through the observations of day-to-day work life. Interactions between a culture's members and newcomers or outsiders, arrangement and use of workspace, and organizational celebrations are a few of the types of intangible events that might seem innocuous, but prove valuable in the study of an organization's culture. Symbols, sagas, and ceremonies are three of the key ways in which a culture's tacit knowledge takes on an explicit form in a library. Symbols are perhaps the most crucial aspect of a culture. Symbols are objects, not necessarily physical, that hold meaning for the members of the organization. The meaning of the symbol expresses in some ways the values the organization holds important. A book holds a functional purpose, but to a librarian a book is symbolic of knowledge. Librarians place a great deal of importance on books because of their deeply ingrained values to protect and preserve knowledge. An effort to replace books with e-readers may provoke a backlash because of the perceived attack on a deeply held value or preserving knowledge.

Stories, myths, and sagas are one of the earliest and most enduring aspects of human culture. Sagas are crucial in studying and understanding organizational culture as they allow a glimpse into an organization's history. Sagas are stories that blend the history and heritage of an organization in order to explain the present norms and beliefs of its members. While sagas have great benefit for a library, they can also be negative if the only thing librarians and library staff like to talk about are library's heroes from the past. In this environment, it can be difficult to focus on the future and move forward.

A rite or ritual is an important artifact of culture and may be defined as a regular organizational activity that carries more meaning than it does actual purpose. It is easy for leaders of an organization to state their values, but rites and rituals openly publicize the values of an organization. If a library places great value on its people, then the library will hold ceremonies like parties that bring together and celebrate its people. Disconnects between stated values and those values that are celebrated can cause a fracture in the culture of a library.

The importance of studying organizational culture in libraries lies in what it can tell us about professional librarians and paraprofessional staff. By understanding the culture, one gains an understanding of the underlying values and assumptions of the organization and what motivates and drives the behavior of those within the organization. It is through understanding these underlying values and assumptions that leaders gain true insight into their libraries. By studying the culture of a library, one can better understand the motivations and assumptions of those librarians, library staff, and administrators working within the library. This understanding can foster better relations between librarians, administration, and various user groups, help find useful ways to motivate and reward librarians and library staff, and help direct change management. $\boldsymbol{n}$

\section{Upcoming ACRL e-Learning}

Looking to expand your professional development horizons? ACRL is offering a variety of online seminars and Webcasts this summer. Upcoming topics include:

Creating a "Social Life" for Information Literacy Instruction in Libraries (Online Seminar: July 9-27, 2012)

Instructional Design for Online Teaching and Learning (July 16-August 10, 2012) Online Seminar:

Lightning in a Bottle: Managing Ideas to Spur Innovation (Webcast: July 17, 2012) Statistics for the Non-mathematical Mind (Online Seminar:July 23-August 10, 2012)

Visit the ACRL e-Learning Web site at www. ala.org/acrl/onlinelearning for complete details. 